testimonial given to him on his retirement. Of the old students subscribing, fifteen were in India, ten in Africa, seven in the British West Indies, seven in the Federated Malay States and Borneo, six in Egypt, five in Ceylon and a number in Australia, New Zealand, Burma, Iraq and Japan.

In the pursuit of these aims Farmer did not, however, allow the torch of pure learning to be dimmed. He had wide interests in botany and published work in various fields, and he did distinguished work as a cytologist before the boundary between cytology and genetics had broken down. In 1907 he gave the Croonian Lecture of the Royal Society-of which he had become a fellow in 1900-his subject being the "Structural Constituents of the Nucleus and their Relation to the Organization of the Individual". He received a Royal Medal in 1919 and was a vice. president during 1919-21. Farmer was a writer of clarity and directness, qualities which he himself ascribed to a youthful drilling in Latin. He wrote several smaller books on elementary botany and with A. D. Darbishire edited the translation of "Die Mutations Theorie" by de Vries. He organized and during its early years was editor of Science Progress. He edited also the Gardeners' Chronicle during 1904-7 and for a number of years the Annals of Botany.

Farmer, with his broad scientific knowledge, his grasp of affairs and his powers of decision, was naturally in great demand where the organization of what might be called plant technology was concerned. He was a member of the small Inter-Departmental Forestry Committee, on the report of which the Imperial Forestry Institute was founded. He served on the Milner Committee, and played a large part in the establishment of the Imperial College of Tropical Agriculture in Trinidad. He was a member of the Advisory Council of the Department of Scientific and Industrial Research from 1920 until 1926, and it was during that period that the Forest Products Research Board was organized, and he was its first chairman. To the Empire Cotton Growing Corporation, especially in its early years, Farmer gave notable service. On behalf of the Corporation he and Mr. L. G. Killby visited Trinidad in 1925, and as a result of their report the Cotton Research Station was set up in 1926. He also gave invaluable advice and help when the Corporation established a postgraduate studentship scheme for the recruitment of its staff. Later he was to serve on a committee set up by the Secretary of State for the Colonies to inquire into the training of agricultural officers for the Colonies. Farmer, from his experience of the Corporation's scheme of postgraduate studentships, advocated a similar one for the Colonial Oifice. As a result of the Committee's report an entirely new scheme of recruitment for the Colonial Agricultural Service was established. Farmer's advocacy was of the greatest value, for the scheme brought about an almost revolutionary improvement in the qualifications of the Colonial agricultural officer. Farmer was active in many other ways-as a member of the Research Committee of the Rubber Growers' Association, of the Royal Commission for the Exhibition of 1851, and of the governing body of the Imperial College, on which he served from its establishment in 1907 until his retirement. He was knighted in 1926.

Farmer was a man built on generous lines both in mind and body. He stood well over six feet, and the big muscular hands of his large-boned frame were equally good at cutting a botanical section, tying a fly, or giving confidence on the rope to the tyro whom be was instructing in the craft of rock climbing ; for he was botanist, fisherman, mountaineer and, not least, gardener. In all these pursuits Farmer was the born teacher, always ready to pass on his knowledge, and delighted if he could inoculate others with his enthusiasm. Farmer was a steadfast friend, and since to a knowledge of men and affairs he added the quality of 'allroundaboutness' of outlook, one could go to him in a difficulty with the certainty of receiving counsel of rare balance and wisdom.

V. H. BLACKMAN.

\section{Prof. J. W. H. Eyre}

BRITISH bacteriology and Guy's Hospital both lost an outstanding personality when Prof. J. W. H. Eyre, emeritus professor of bacteriology in the University of London, recently died at the age of seventy-five. Entering Guy's as a medical student in 1889, he qualified in the minimum time, graduated M.D., M.S., in the University of Durham and received his first hospital appointment. This initial experience as registrar in the Ophthalmic Department was an appropriate introduction to the delicate, small-scale experimental laboratory work to which he was later to devote his life. In fact, his first research, though ophthalmic, was essentially bacteriological, culminating in his description of tuberculosis of the conjunctiva which stands a classic to this day. At that time (1895) all hospitals, realizing the great future of medical bacteriology, were developing laboratories accordingly, and inevitably Eyre was attracted by this new trend. In 1899 he gave up eye work entirely for the post of bacteriologist to Charing Cross Hospital, where he became the first Ernest Hart Memorial Research Scholar and at once began to devise new technical methods, and showed such genius for the work that three years later he was invited to occupy the corresponding post at his own hospital. He never again left Guy's and there centred the whole of his remarkably industrious and productive career.

In 1905 he was invited by the Royal Society to join the Advisory Board of the Commission on Mediterranean Fever. Working overseas as chairman of the team experiment ing in Malta he was associated with a number of results which did much to advance our early knowledge on Brucella infections and paved the way to their ultimate control. Retırning home he resumed his former work of bringing law and order into the still somewhat chaotic state of routine bacteriological investigation, and shortly after published his standard work, "The Elements of Bacteriological Technique", which, when consulted to-day, shows us his pioneer conception of a remarkable number of modern methods. About this time he was elected a fellow of the Royal Society of Edinburgh. Soon, bacteriological diagnosis becoming more accurate, he found it possible to give his research a more direct medical bearing, and over this period he published with his clinical colleagues many case notes on infective disease.

Most notable, perhaps, was his work on the varieties of pneumococi associated with different respiratory infections, a true forerunner of later developments, and also his proof that much institutional dysentery was really of the Flexner type. Meanwhile the amount of work entering the laboratories at Guy's was in. creasing so rapidly that the Governors of the Hospital wisely decided to develop a new and completely up-to-date department. This they entrusted to Eyre, 
giving him an entirely free hand, and the result was possibly one of his major contributions to his subject. For many years his laboratory stood as a model for others, both as to its design and its system of records, references and accounts. It was, in fact, still meeting every demand made upon it even at the time of his retirement twenty-five years later, a remarkable example of his exceptional skill as organizer as well as scientific worker. Its opening coincided with the outbreak of the War of 1914-18, and as might be expected, although the Department was never under direct Government control, a very large amount of work directly aiding the Services passed through it. Eyre's peace-time activities had brought recognition in the form of appointments as Erasmus Wilson Lecturer and Hunterian Professor at the Royal College of Surgeons and Milroy Lecturer before the Royal College of Physicians.

The moment war broke out he placed the facilities of the laboratory at the Covernment's disposal, and the first big work undertaken concerned the urgent task of systematically detecting the many typhoid and paratyphoid carriers returning from the British Expeditionary Force. Methods were standardized and compared and a complete system instituted which must have prevented many home outbreaks. In 1915 Eyre was appointed as a civilian pathologist in the London District Command, and co-operated in improving and selecting the various anti-enteric vaccines which later proved so successful in France. Then the second great war-time infection threatened, namely, cerebro-spinal fever, and his laboratory again was active in investigating both meningococcal carriers and acute infections. It is interesting to note in his reports of those days how he insisted, and was ultimately proved correct, that cerebro-spinal meningitis is primarily a septicæmia. A little later, these urgent investigations being over, Eyre turned his attention to the then somewhat inadequate bacteriological facilities available to the many semi-private military hospitals which were springing up all around London, and we find him displaying really astonishing energy as honorary bacteriologist to a very large number of them. Military, Royal Flying Corps, and American units were included, and the volume of personal work he must have got through at that period was enormous.

When the influenza epidemic attacked Great Britain, Eyre at once found himself involved in the investigation of the prevailing secondary respiratory tract infections and the possibility of preventing them by prophylactic vaccine. In this case he was particularly concerned with the New Zealand Forces, and at one period his Department placed half a million doses of vaccine at the disposal of the Army Medical Department of the War Office inside seven days. Records show how greatly this work must have reduced the incidence of complications. In April 1918 he was invited to join the Trench Fever Committee of the War Office and co-operated in proving this disease to be louse-borne, although the War ended before the exact nature of the organism could be deterrrined. His final war-time contribution was as a member of the Chemical Warfare Committee of the Medical Research Council, the work of which guaranteed our preparedness in that sphere at least.

The return to peace conditions called for considerable departmental reorganization, and Eyre's was one of the first to get into its stride again. A rapidly expanding venereal disease clinic at his hospital brought new volumes of serological work, and be was concerned with many serial observations on the comparative value of the Wassermann reaction and the various flocculation tests for syphilis. Also Sonne dysentery was coming to be recognized as a real threat to institutional life, and one of the earliest fully recorded outbreaks was observed in his laboratory.

Having held a readership for many years, Eyre was in 1920 appointed professor of bacteriology in the University of London, and from then onwards his activities in medical societies and committees became even greater. He had been president of the Section of Bacteriology and Pathology at the British Medical Association meetings of 1933 and became president of the Royal Microscopical Society in 1920. I Later he held the same office in the Hunterian Society and the Royal Institute of Public Health and Hygiene. $\mathrm{He}$ attended many overseas meetings and was well known on the Continent. His editorship of the English translation of Kolle and Hetch's "Experimental Bacteriology" was admirable.

Although the scientific world will remember Eyre chiefly as an inventor of technique, his colleagues at hospital always realized that he had considerable clinical gifts. He was always about the wards and his advice freely taken. He produced with Dr. Bosanquet a most useful little manual, "Serums, Vaccines and Toxins in Treatment and Diagnosis". The passing years never seemed to affect his remarkable energy, and his strong personality carried him along, always in harness, to the very end. An interesting appointment which he held for a good many years was that of bacteriologist to the Worshipful Company of Fishmongers, and he may be said to have thereby con. trolled the bacteriological purity of the nation's fish supplies, doubtless preventing innumerable epidemics. But this work had its essentially scientific side also, and he produced several beautifully illustrated monographs on the bacteriology of the edible molluses.

His colleagues at Guy's will always remember the minute, neat, intensely active figure of "Johnny" Eyre. Everyone knew, honoured and loved him and, when he retired from the active staff of the Hospital in 1934, gave him a memorable farewell dinner. But he never entirely deserted his Medical School, and was seen about the laboratories less than a week before his tragically sudden death. Those who actually worked with him will greatly miss the inspiration which he always gave to them and his unfailing interest in the welfare of everyone ever connected with his old Department. There are many working in the medical laboratories of to-day who, for the excellence of their earlier training, owe him a very great debt of gratitude.

F. A. KNotr.

We regret to announce the following deaths:

Dr. J. McKeen Cattell, editor of Science since 1894, and also of other American scientific journals, on January 20, aged eighty-three.

Mr. A. W. Clayden, principal during 1894-1920 of University College, Exeter, known for his reports to the British Association on the measurement of cloud altitudes, aged eighty-eight.

Mr. A. Eidinow, of the National Institute for Medical Research, London, known for his work on the principles of ultra-violet ray therapy, on March 22.

Dr. James H. Kimball, since 1936 principal meteorologist of the U.S. Weather Bureau, on December 21, aged sixty-nine. 